\title{
Portrayal of the Germani in Latin Textbooks in Germany, 1945-1989
}

\author{
James David McNamara ${ }^{1}$ D
}

Accepted: 22 September 2020 / Published online: 2 November 2020

(c) The Author(s) 2020

\begin{abstract}
This article is a contribution to the history of classical education, focused on the reception of Roman texts about Germania in German schools between 1945 and 1989. The period under discussion here represents a time during which there was an aversion to handling material tainted by its appropriation under Nazi ideology, and traces the development of new approaches to its treatment.
\end{abstract}

***

The present article serves as a sequel to an earlier publication which traced the representation of Germani in German Latin textbooks from the 1870s until 1945. ${ }^{1}$ This article shows how material tainted by its appropriation in National Socialist ideology was handled in the Federal Republic of Germany in the years between 1945 and German reunification. Subsequent developments are the subject of another detailed study. ${ }^{2}$ The minority status of Latin teaching in the German Democratic Republic means that the available sources for the place of Germani in Latin teaching are

\footnotetext{
1 J. McNamara, 'Lehrbuchgermanen: the representation of the Germani in Latin textbooks in Germany from the late nineteenth to the mid-twentieth century', Pegasus Onlinezeitschrift, 15.1, 2015, pp. 83-155.

2 J. McNamara, 'The Portrayal of Germani in German Latin Textbooks, 1989-2009', Syllecta Classica, 30, 2019, pp. 73-108.
}

I would like to thank Prof Arthur Pomeroy and Dr Babette Puetz, who supervised the research on this project at Victoria University of Wellington, and Prof Stefan Kipf for advice and for providing access to resources during a research stay in Germany.

The research was initially conducted during an MA in Classics at Victoria University of Wellington. The thesis was deposited in the Victoria University of Wellington library and is available in the library's archive, but it has never been published as a whole. Parts of the thesis have been submitted for publication elsewhere, but this section is unpublished and is not under consideration for publication anywhere else.

James David McNamara

james.mcnamara@cantab.net

1 Universität Potsdam, Am neuen Palais 10, 14469 Potsdam, Germany 
mostly to be found in the Federal Republic during these years. ${ }^{3}$ The main thread is the representation of Germani in school education, but a detailed study of this subject reveals much about attitudes towards Classical teaching and scholarship more broadly. The main sources for tracing the history of Latin teaching in the classroom in this period are textbooks, though the 'triangle' of pedagogical developments, academia and broader social and cultural changes is always to be kept in view. ${ }^{4}$

Despite briefly flourishing in West Germany in the 1950s, Latin was widely criticized after the Second World War as a subject unsuited to educating the future citizens of a modern democracy: it was irrelevant to modern society, narrow in its content ('war and grammar'), provided material that was unsuitable or unpalatable for children and was a distraction from learning modern languages. ${ }^{5}$ Classical Humanist education came under fire for what was perceived as its moral ineffectuality in having been unable to prevent the barbarism of National Socialism from taking hold. ${ }^{6}$ This criticism was aimed primarily at the Humanist Gymnasien, where the classical languages were the backbone of a child's education. Although there were some attempts to modernize the teaching of Latin in the years leading up to 1970, the first step in abandoning the legacy of the Third Reich was to re-build Latin teaching on the foundations laid in the Weimar Republic. ${ }^{7}$ It was not until the "crisis' of the ancient languages in the early 1970s that the 'neue Fachdidaktik' caused radical changes in the teaching of ancient languages, amongst which was a departure from

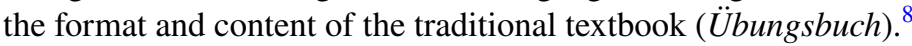

There was nothing new about the status of Latin as a focus for arguments in favour of educational reform during the $1960 \mathrm{~s},{ }^{9}$ though a large number of

\footnotetext{
${ }^{3}$ On classical language teaching in the DDR see H.-J. Fischer, Der altsprachliche Unterricht in der DDR. Entwicklung, Funktion und Probleme des Latein- und Griechischunterrichts von 1945 bis 1973, Paderborn, 1974.

4 On the 'didactic triangle' see S. Kipf, Herodot als Schulautor, Cologne/Weimar/Vienna, 1999, pp. 2-5.

5 H.-J. Apel, 'Altsprachlicher Unterricht - Deutschland', in Der Neue Pauly, ed. M. Landfester, Stuttgart, 1999, pp. 114-19 (115). S. Kipf, Altsprachlicher Unterricht in der Bundesrepublik Deutschland, Bamberg, 2006, pp. 20-35 provides a thorough discussion of the position of school Latin in German society after 1945.

${ }^{6}$ P. Schmidt, 'Latin Studies in Germany, 1933-1945: Institutional Conditions, Political Pressures, Scholarly Consequences' in Texts, Ideas and the Classics, ed. S. Harrison, Oxford, 2001, pp. 285-300 (286).

7 On the return to Weimar traditions, see: E. Habenstein, 'Erinnerungen an Lateinbücher', Der altsprachliche Unterricht, 6.5, 1963, pp. 42-50 (50). A. Fritsch, 'Sprache und Inhalt lateinischer Lehrbuchtexte. Ein Unterrichtsgeschichtlicher Rückblick' in Abhandlungen aus der pädagogischen Hochschule Berlin 3, ed. W. Heistermann, Berlin, 1976, 116-19 (152 ff.), Kipf, Altsprachlicher Unterricht (n. 5 above).

${ }^{8}$ For the term 'neue Fachdidaktik', see Apel, 'Altsprachlicher Unterricht' (n. 5 above), p. 115. 'Kopernikanische Wende' is used by Kipf, Altsprachlicher Unterricht (n. 5 above), p. 176.

9 For ancient languages as a prime target of educational reform movements in the Weimar Republic, notes the polemical remarks of P. Oestreich, 'Kaiserliche und volksstaatliche Schulreform' in Stettiner Volksbote, 216, 1920; reprinted: P. Oestreich, Entschiedene Schulreform. Schriften eines politischen Pädagogen. Eingeleitet, ausgewählt und erläutert von König, Helmut und Radtke, Manfred, (Ost-)Berlin, 1978, pp. 106-11: 'Schulreform hieß der Streit um mehr oder weniger Latein oder Griechisch', ('School reform meant the battle over more or less Latin or Greek') cited by G. Winands, 'Die Schulversuch in Geschichte und Gegenwart' in Handbuch Bildungsreform und Reformpädagogik ed. H. Barz, Wiesbaden, 2018, 143-54 (146). On the principles of educational reform in the Weimar Republic, see R. Dithmar ed., Schule und Unterricht in der Endphase der Weimarer Republik, Berlin, 1993.
} 
educationists opened up the debate on new fronts. Latin was criticized as irrelevant to the modern world and to pupils' requirements as future members of the workforce and contributors to the economy. The difficulty of Latin and its role as a subject that marked out the best pupils, which had often been touted as positive qualities, came to be regarded negatively as elitism and socio-economic selection unsuited to a democratic school system. ${ }^{10}$ The subject matter and its interpretation came under scrutiny. The heavy weight of military topics (especially in the almost inevitable reading of Caesar's Gallic War, but also in other authors, such as Livy) was much criticized. ${ }^{11}$ Certain ideologies that pervaded the institution of Latin teaching were also increasingly seen as out of place, notably the idealization of conservative Roman values. ${ }^{12}$ Amongst educationists there was a strong tendency through the 1960 s to criticize Neuhumanismus and its ideal of the general education of the individual, on the grounds that it was too focused on an apolitical Innerlichkeit (an inward turn of mind) rather than current social and political realities. ${ }^{13}$ Georg Picht used the word Bildungskatastrophe to describe what he saw as the failure of the secondary school system, the function of which was, 'den qualifizierten Nachwuchs auszubilden, der die gewaltige Maschinerie der modernen Wirtschaft und Gesellschaft in Gang halten soll' ('to educate the younger generation, who were to maintain the massive machinery of the modern economy and modern society'). ${ }^{14}$

A number of political changes during the period 1945-1970 were made to the detriment of Latin and Greek in schools. Probably the greatest setback was the 'Düsseldorfer Abkommen' of 17 February 1955, in which the Humanist Gymnasium had its existence assured, but only insofar as it was able to compete successfully with other types of school, including Gymnasien with science or modern-language specialties. In these kinds of Gymnasium, Latin was to be available as a second or third foreign language after English, though there were moves to introduce a choice

\footnotetext{
10 Apel, 'Altsprachlicher Unterricht' (n. 5 above), pp. 115-16.

11 On Livy: Kipf, Altprachlicher Unterricht (n. 5 above), p. 158. On the predominance of military themes: A. Fritsch, 'Sachkunde im Anfangsunterricht. Ein Überblick', Der altsprachliche Unterricht, 34.5, 1991, pp. 4-22 (4). On the predominance of Caesar: Fritsch (ibid.) p. 4; S. Kipf, 'Aut Caesar aut nihil?', Pegasus Onlinezeitschrift 2+3, 2006, pp. 28-46.

12 K.-D. Thieme, 'Ora et labora! Anmerkungen zur Ideologie lateinischer Lehrbücher', Berliner LehrerZeitung, 8-9, 1969, pp. 18-25. A. Fritsch, 'Sachkunde im Anfangsunterricht. Ein Überblick', Der altsprachliche Unterricht, 34.5, 1991, pp. 4-22 (4).

13 Kipf, Altsprachlicher Unterricht (n. 5 above), pp. 25-26. For Wilhelm von Humboldt and Neuhumanismus see M. Landfester, 'Neuhumanismus' in Der neue Pauly, ed. M. Landfester, Stuttgart, 1999, pp. 918-25, and H. Becker, G. Kluchert, Die Bildung der Nation. Schule, Gesellschaft und Politik vom Kaiserreich zur Weimarer Republik, Stuttgart, 1993, pp. 49-81.

14 G. Picht, 'Zehn Thesen über die höhere Schule', in Die Verantwortung des Geistes (1965) Olten/ Freiburg im Breisgau, pp. 85-99 (92). Cited by Kipf, Altsprachlicher Unterricht (n. 5 above), p. 27. Picht recommends, furthermore, that the annual numbers of Abitur-candidates be doubled, an approach which impinged negatively on Latin and Greek as subjects that had long been considered to perform the function of selecting the most able students: Kipf, Altsprachlicher Unterricht (n. 5 above), pp. 27-30. For further discussion of the 'Bildungskatatrophe' see G. Picht, Die deutsche Bildungskatatrophe: Analyse und Dokumentation, Olten, 1964. For an overview of the aims and consequences of educational reform in the 1960s see S. Liebenwein, 'Bildungsreformen in der BRD' in Handbuch Bildungsreform und Reformpädagogik, ed. H. Barz, Wiesbaden, 2018, pp. 129-42 (129-33).
} 
between Latin and French in Quarta. ${ }^{15}$ During the same period there was a decline in the number of hours available for Latin in school timetables. In the 1925 Richtlinien, 53 hours of contact time (Wochenstunden) were set aside for Latin as the first foreign language from year 5 onwards. ${ }^{16}$ By 1958, the figure had dropped to 44 in Hessen, 47 in Baden-Württemberg and 49 in Bavaria and North Rhine-Westphalia. In schools with Latin as second foreign language, the first four years (7-10) involved a total of 17 Wochenstunden in Bavaria in 1963, (similarly, 15 in Berlin, and 17 in Baden-Württemberg, while North Rhine-Westphalia had 18 and Hessen 19 in 1961). By way of comparison, Bavarian Humanist Gymnasien offered 22 Wochenstunden for the same years. It was widely recommended that four hours per week be offered in each year of the Oberstufe (years 11-13). ${ }^{17}$

Due to associations with the racist ideology of National Socialism there was a decline in the volume of scholarship on Germania produced after 1945. Dieter Timpe's introduction to the proceedings of the Kommission für die Altertumskunde Nord- und Mitteleuropas of 1986 discusses whether it is justified for such colloquia to take Tacitus's Germania as their topic. ${ }^{18}$ Manfred Fuhrmann's article in the same publication observes that, since 1945, there was 'nicht sonderlich viel über die Germania des Tacitus zu berichten' ('not a great deal to report regarding Tacitus's Germania'). ${ }^{19}$ Whereas the 1920 s and 1930s had produced three commentaries on the Germania in a short space of time, those of Fehrle (1929), Reeb (1930) and Much (1937), the only commentaries published in the years 1945-1988 were, in 1959, edited versions of Fehrle's and Much's commentaries and, in 1967, an edition of Much considerably augmented by archaeological information. ${ }^{20}$ Until 1988, therefore, when Alan Lund's commentary was published, teachers had to rely on out-ofdate works harking back to the time when 'Germanomania' impinged upon the work of many scholars. ${ }^{21}$

Germania remained amongst the recommended texts for the Oberstufe of Latin at the Gymnasium. Stefan Kipf's survey of important works on Latin teaching methodology used in the 1960s shows that Tacitus's Germania is recommended as a set text for the Oberstufe (years 11-13) by Krüger/Hornig (1959), Wilsing (1964), Klinz (1963) and Jäkel (1966). Notably, it is only the earliest of these (Krüger/Hornig) that

\footnotetext{
15 Kipf, Altsprachlicher Unterricht (n. 5 above), p. 23.

1653 is the sum of the Wochenstunden (hours per week) for each year level from 5 to 13 .

17 Kipf, Altsprachlicher Unterricht (n. 5 above), pp. 30-31.

18 D. Timpe, 'Einleitung' in Beiträge zum Verständnis der Germania des Tacitus, ed. H. Jankuhn, D. Timpe, Göttingen, 1989, pp. 7-15.

19 M. Fuhrmann, 'Die Germania in der Forschung der klassischen Philologie und im gymnasialen Unterricht' in Beiträge zum Verständnis der Germania des Tacitus, ed. H. Jankuhn, D. Timpe, Göttingen, 1989, pp. 180-97 (180-4).

${ }^{20}$ Fehrle's commentary appeared in the following editions: $1929,{ }^{2} 1935,{ }^{3} 1939,{ }^{4} 1944$. Much's was published as follows: $1937,{ }^{2} 1959,{ }^{3} 1967$.

21 The journal Gymnasium, as late as 1952, published a lecture given by Hans Drexler in 1944 and 1945. Drexler was one of the chief ideologues of National Socialism. See Schmidt, 'Latin Studies' (n. 6 above), pp. 289-300.
} 
recommends Germania for year $11 .^{22}$ The difficulty of Tacitus's Latin and a generally observed decline in the quality of pupils' Latin meant that it was increasingly unlikely for Germania to be read so early. As a 1964 catalogue of the 157 school editions of all Latin authors approved for use in Bavaria shows, Tacitus is the author with the second-highest number of school editions of his works available, the first six being as follows: ${ }^{23}$

\begin{tabular}{lll}
\hline Author & $\begin{array}{l}\text { Number of approved school editions in circula- } \\
\text { tion }\end{array}$ & $\begin{array}{l}\text { Percentage of total } \\
\text { approved editions (\%) }\end{array}$ \\
\hline Cicero & 33 & 21 \\
Tacitus & 12 & 7.6 \\
Caesar & 11 & 7 \\
Horace & 9 & 5.7 \\
Livy & 9 & 5.7 \\
Sallust & 8 & 5.1 \\
\hline
\end{tabular}

Of course, the number of available editions is not an accurate reflection of the number of pupils being taught from a particular text; this activity in the publishing sector does, however, reflect in a more general way the continuing interest in Tacitus as a school author.

Articles by Hans Martens (1962) and Hans Königer (1967) address the question of how to interpret Tacitus in school. It is clear from both articles that Germania is still a commonly read constituent of the Oberstufe-canon. Königer refers to the place of Latin in the Bavarian curriculum when he says,

An Schulen mit Latein als zweiter bzw. dritter Fremdsprache wird die 'Germania' in Klasse 12 oder 13 gelesen, an alt- und neusprachlichen Gymansien mit grundständigem Latein ist eine Auswahl aus dem taciteischen Gesamtwerk obligatorisch. $^{24}$

At schools with Latin as second or third foreign language, Germania is read in year 12 or 13; at modern or ancient language gymnasia with Latin as first foreign language, a selection from Tacitus's Germania is compulsory.

\footnotetext{
$\overline{{ }^{22}}$ M. Krüger, G. Hornig, Methodik des altsprachlichen Unterrichts, Frankfurt a.M., 1959; N. Wilsing, Die Praxis des Lateinunterrichts, Teil II: Probleme der Lektüre, Stuttgart, 1964; A. Klinz, 'Die Rolle der Schulschriftsteller' in Lateinausbildung im Studienseminar, ed. E. Ahrens, Frankfurt a.M., 1963; W. Jäkel, Methodik des altsprachlichen Unterrichts, Heidelberg, 1966.

${ }^{23}$ Table copied from Kipf, Altsprachlicher Unterricht (n. 5 above), p. 147, citing data from the Amtsblatt des bayerischen Staatsministeriums für Unterricht und Kultus 7, 1964, pp. 124-36.

${ }^{24}$ H. Königer, 'Zur Methode der Tacitus-Lektüre am humanistischen Gymnasium', Der altsprachliche Unterricht, 10.5, 1967, pp. 97-124 (101), citing Das Amtsblatt des bayerischen Staatsministeriums für Unterricht und Kultus, 16 (26/08/1964), pp. 347-50. Oberstufe refers to the years 11-13 of the Gymnasium. When counting school years in this manner, secondary school typically begins at year 5 , with pupils normally aged 10 or 11 ; pupils in year 13 would normally be 18 or 19 years old. The older system of age-groups is occasionally used in some of the textbooks discussed below. The first year of secondary education was thereby called Sexta (age 10 or 11), followed by Quinta, Quarta, Untertertia, Obertertia, Untersekunda, Obersekunda, Unterprima, Oberprima.
} 
Germania seems, therefore, in Bavaria at least, to have retained its position as one of the crowning texts of school Latin. ${ }^{25}$ Nevertheless, Königer later states, 'Freilich kann Tacitus nur in Auswahl gelesen werden, selbst aus der "Germania" wird man den allgemeinen ethnographischen Überblick (Germ. 1-27) herausgreifen' ('Admittedly Tacitus can only be read in selections; even in the Germania one will select the general ethnographic overview (Germ. 1-27) ${ }^{26}$ Surveying the school editions of Tacitus that are in use and in print, Königer lists 15 editions of the opera minora with commentary, including 11 of Germania, along with only one of the Histories and 14 editions of selected passages from the Annals (some of which also include material from the Histories). Both Königer and Martens point out the difficulty of Tacitus's language as well as his complex handling of subject matter and mention particular difficulties involved in interpreting Germania. Martens states that Germania is usually the first of Tacitus's texts to be read in school and observes that a focus thereafter on the Batavian revolt and the campaigns of Germanicus may give a false impression of Tacitus as a 'Schriftsteller von Germanenkriegen im Sinne einer Fortsetzung Cäsars unter veränderten sprachlichen Bedingungen' ('author of Germanic wars as a continuator of Caesar under changed linguistic conditions'). ${ }^{27}$ Königer makes pertinent recommendations for the interpretation of Germania in the context of 'Primitivenromantik' ('romanticizing of the primitive') with the concepts 'Imperium - Fremdvölker' ('empire - foreign peoples') as a guiding thread. He recommends some study of the text's more recent reception history starting with Heinrich von Kleist's Hermannsschlacht as 'ein frühes Beispiel chauvinistischer Befangenheit' ('an early example of chauvinistic bias'). ${ }^{28}$ It is noticeable that despite some attempts to introduce new themes and Leitgedanken (key ideas) to guide the interpretation of Germania, the Germani of school textbooks, though no longer dominating the scene as they had under National Socialism, generally reverted to the types familiar from the Weimar Republic and earlier. Consequently, those pupils who did not take Latin as their first foreign language would encounter little but traditional Germanic clichés during the course of their Latin at school. Klaus von See sums up these clichés as follows:

...rauh und kriegerisch gesinnt und dabei offenherzig und bieder, den althergebrachten, bäuerlich-bodenständigen Sitten verhaftet, von keuscher, schlichter Ehrbarkeit in der Achtung der Frau und des Gastfreundes, abgeneigt dem Händler- und dem Advokatentum, im politischen nicht institutionell-etatisch denkend, sondern auf die natürlichen, gewachsenen Gemeinschaften von Fam-

\footnotetext{
25 Bavaria, it should be observed, is the state that has traditionally had the highest proportion of pupils learning Latin. C. \& W. Riess, 'The State of Latin Instruction in Germany Today', The Classical Journal, 101.2, 2005/6, pp. 191-9 (194).

${ }^{26}$ H. Königer, 'Zur Methode der Tacitus-Lektüre am humanistischen Gymnasium', Der altsprachliche Unterricht, 10.5, 1967, pp. 97-124 (102).

27 H. Martens, 'Gedanken zur Tacituslektüre', Der altsprachliche Unterricht, 5.5, 1962, pp. 52-83 (53).

28 Königer, 'Zur Methode' (n. 26 above), pp. 105-8.
} 
ilie, Sippe und Stamm bauend und auf die persönliche Treuebindung zwischen Gefolgsherr und Gefolgsmann. ${ }^{29}$

...with a character that was rough and warlike, but at the same time candid and respectable, attached to the ancient down-to-earth customs of the farmer, of chaste, simple respectability in honouring women and guests, averse to the ways of merchants and lawyers; in politics, not thinking less in terms of institutions and the state but building on the natural, organic communities of family, clan, tribe and on the personal ties of loyalty between a leader and his sworn followers. ${ }^{30}$

The 'first generation' of textbooks after World War II (those published up until the early 1970s) tended to display 'einen restaurativen Charakter', looking back to the Weimar Republic and the spirit of the 1925 Richtlinien. ${ }^{31}$ Ludus Latinus, for example, was re-edited and re-issued up until 1969. ${ }^{32}$ The subject matter of these textbooks generally reflects their foundation in traditions of the Weimar Republic. The textbooks studied in some detail here are the C-Version of Krüger's Lateinisches Unterrichtswerk, re-editions of Ludus Latinus, Exercitia Latina for Latin as a second foreign language, and Lingua Latina for Latin as a third foreign language. ${ }^{33}$ The sources presented here are included based on the presence of significant passages relating to Germania or because they are new editions of textbooks that show significant revisions. Given that textbooks that have outlived their usefulness in the classroom are handled more or less as ephemera, it is difficult to trace all the editions of textbooks that are as old as those under investigation here. My source base cannot claim to be comprehensive of all textbooks with significant material relating to Germania from this period, but it is the most extensive collation of such material that I am aware of, based on a period of research in university libraries, primarily at FU and HU Berlin, the Fachdidaktik collection at FU Berlin, augmented by loans from private libraries and specific volumes tracked down through the Zentrales Verzeichnis Antiquarischer Bücher (www.zvab.com).

\footnotetext{
${ }^{29}$ K. Von See, Deutsche Germanenideologie, Frankfurt a.M., 1970, p. 11.

${ }^{30}$ Gefolgsherr and Gefolgsmann are terms drawing directly on the description of ties between a Germanic princeps and his comitatus (the collective noun for his band of sworn followers, generally translated in German as Gefolgschaft) at Tac. G. 14.1-2.

31 Habenstein, 'Erinnerungen' (n. 7 above), p. 50. See also A. Fritsch, 'Die Lesestücke im lateinischen Anfangsunterricht. Ein Beitrag zur Geschichte des lateinischen Lehrbuchs', Der altsprachliche Unterricht, 21.4, 1978, pp. 6-37 (22). The terminology used here is that outlined by Kipf, Altsprachlicher Unterricht (n. 5 above), p. 55, n. 126, according to which the 'first generation' consists of textbooks published in the years 1945-1970, the second 1970-1990, and the third through the 1990s up to the 'fourth generation' from 2004.

32 Ludus Latinus, like other textbooks of the Weimar period, had been composed under the influence of the Kulturkunde movement, which placed children's knowledge of their own culture at the centre of educational development. So important was German culture at the heart of the curriculum that Latin textbooks of the period include a large amount of subject matter drawn from modern Germany as well as ancient Germania, frequently glossed as 'Deutschland'. For discussion see McNamara, 'Lehrbuchgermanen' (n. 1 above), pp. 103-4.

33 Krüger's textbook was published in three versions: A, for Latin as second foreign language; B, for Latin as third foreign language; $\mathrm{C}$, for Latin as first foreign language.
} 
Textbooks of the years 1945-1970 generally display an idealized view of the ancient world similar to textbooks of the Weimar Republic and even earlier textbooks like Ostermann. The Germani are still generally to be encountered in uncritical adaptations of texts from Caesar and Tacitus. In many of the textbooks produced during this period, 'werden römische Charaktereigenschaften in unreflektierter Idealisierung hervorgehoben' ('aspects of Roman character are unreflectively idealized'), and traditional subject matter continues to predominate. ${ }^{34}$

The most successful coursebook of the Weimar Republic, Ludus Latinus, was revived after the Second World War. The new editions differed little from their predecessors in regard to methodology, but the content of the texts has been considerably altered, the biggest change being the excision of much German and Germanic subject matter and the revision of that which remains. ${ }^{35}$

Ludus Latinus I B of 1963 opens, as the 1932 edition had, with a paragraph headed Zur Vorbereitung. ${ }^{36}$ Whereas the earlier version had welcomed pupils with a short narrative about the first day at school as a Sextaner, punctuating the text with Latin vocabulary used at school and quoting Paulus, the ubiquitous Lateinbuch schoolboy, the newer Ludus Latinus restricts itself to observations on the Latin origins of many German words, as in the sentence, 'Paul studiert an der Universität Köln Medezin'. The modern school has moved away from being the 'Latin country' of earlier times, and rather than taking for granted that Latin is an integral part of the world of school and one's education in general, the new textbooks often include 'Legitimationsstücke' that justify Latin by reference to its usefulness or its superior qualities as a means of mental training. ${ }^{37}$

\footnotetext{
${ }^{34}$ Quotation by: Kipf, Altsprachlicher Unterricht (n. 5 above), p. 77. Kipf notes that of the single sentences provided in Bornemann's Lateinisches Unterrichtswerk, approximately one-third are on the topic of war. Bornemann's stated attempt to draw more passages from 'dem "bürgerlichen" Leben und der Umwelt des Schülers' ('middle-class life and the pupils' surroundings', Lat. Unt. Bornemann, teaching materials, 2) manifests itself in passages on rural life and family life, though, as Kipf points out such sentences as 'Paulus cum Ernesto et Friderico equum aegrotum visitat' are not likely to have been genuinely engaging.

${ }^{35}$ By way of comparison it is interesting to note the contents of a publication for British and Commonwealth 'O' level pupils abounding in British content of all historical periods. S. Morris, Experientia. A Modern Practice Book for "O" Level Latin, London/Toronto/ Wellington/Sydney, 1957, includes passages on Britannia, Britain and England adapted from such authors as Caesar, Tacitus and Erasmus, and even presents recent history in a classical light. Especially notable for its patriotism and liberal application of the word Britanni are the passages on the ascent of Mount Everest:

Cum Anglorum regina Elizabeth thronum primo ascenderet, nuntius allatus est montem Everest a Britannis conscensum esse... Et passi sunt et montem superaverunt Britanni illi qui, duce Ioanne Hunt, ex Tamesi flumine profecti, primum in urbem Catamandianam se contulerunt... Primi, deficientibus viribus, mille passus uno impetu ascendere non possunt et redire coguntur. Nunc succendunt alii, Buthia Tensing et Edmundus Hillary. Oxygenio praediti, vexilla cum Cruce ex prioribus excipiunt et stationem ponunt... [S]tatuta est firmiter iam Christi Crux in vertice orbis terrarum et vexilla patria vento panduntur (Experientia, 15, 18).

${ }^{36}$ In this instance, 'B' means the Bavarian version. In what follows, I shall abbreviate references to editions of Ludus Latinus as $L L$. A full list of all the editions of textbooks used in this study can be found in an Appendix.

${ }^{37}$ C. Stray, 'Education' in A Companion to the Classical Tradition, ed. C. Kallendorf, Malden, 2007, pp. 5-14 (6).
} 
As in earlier editions, the Germani make their appearance before the Romans, who are first mentioned in the sentence, 'Romani saepe cum Germanis bellabant', one of the sentences preceding the passage 'Die Römer im Kriege' in chapter 10, the subject matter of which has changed little since 'Die Römer' in the 1932 edition. ${ }^{38}$ The Germani, however, are introduced in a different manner. Whereas Ludus Latinus of 1932 had repeatedly described the hunting of wild animals in the forests (and accompanied the descriptions with illustrations ${ }^{39}$ ), the new version includes a couple of comments about hunting within a description of the Germani in their environment (in 'Von den Germanen I', chapter 9, and 'Von den Germanen II', chapter 11). Both chapters are presented as the words of Paulus, a keen Sextaner who knows about Tacitus. There are no poets praising the fatherland this time. The Germani instead display a rather modern sensibility in their appreciation of the landscape: 'Caelum Germaniae serenum non erat. Sed Germani naturam patriae amabant. Silvae Germaniae magnae et densae erant, campi lati' ( $\left.L L B^{11} I, 4\right)$. These seem to be a deliberately naïve twist on Tacitus's statement, 'quis porro, praeter periculum horridi et ignoti maris, Asia aut Africa aut Italia relicta Germaniam peteret, informem terris, asperam caelo, tristem cultu aspectuque nisi si patria sit?' (Germ. 2.2). The effect of the passage in Germania is to emphasize not Germanic Heimatliebe but rather the improbability of the idea that people would choose to move to Germania from pleasanter climes.

The Germani, in these passages, are farmers, hunters and gatherers. One aspect of the less emotive tone in passages about the Germani is the avoidance of confusion between ancient Germania and modern Germany in the 1963 Ludus Latinus. Instead of a passage entitled 'Arminius, der Befreier Deutschlands' ('Arminius, the liberator of Germany'), there is 'Freiheitsliebe der Germanen' ('The Germanic love of liberty') - note the shift from 'Deutschland to Germanen'. ${ }^{40}$ The new pictures of the Germani are less wild-looking than those of 1926 and $1932 .{ }^{41}$ There is an illustration accompanying the text 'Fürsten und Gefolge' ('Chiefs and their retinue') showing cavalry saluting their chief. The infantry in the background are arranged in an orderly fashion, and although the traditional warlike representation of the Germani continues, the impression is less barbaric than in some earlier portrayals (see Appendix, Figure 1).

The $13^{\text {th }}$ edition of Ludus Latinus II A from 1969 includes none of the 54 pictures that had been included in the $10^{\text {th }}$ edition of 1934 . The pictures had been an important feature in the presentation of the series Ludus Latinus and in making the book attractive to young pupils. There has been no reduction in the grammatical material covered and little alteration to the order in which it is introduced. The most

\footnotetext{
38 McNamara, 'Lehrbuchgermanen' (n. 1 above), pp. 106f.

39 McNamara, 'Lehrbuchgermanen' (n. 1 above), pp. 138, 140.

40 It is uncertain whether the saying, 'Tempora mutantur, nos et mutamur in illis', which follows the text 'Die Germanen: Fürsten und Gefolge' is intended to encourage observations on the foreignness of the ancient Germanic warrior ethic. Many of the texts are followed by choice quotations and sayings, some of which clearly have some relevance to the topic of the text, others of which are wholly unrelated.

41 McNamara, 'Lehrbuchgermanen' (n. 1 above), appendices.
} 
significant alteration to the text is the replacement of seven passages about the Germani, summarized in the table below.

Ludus Latinus II $A^{10} 1934 \quad$ Ludus Latinus II $A^{13} 1969$

1. Die erste Quintastunde

2. Die alten Germanen

3. Ein germanisches Volksthing

4. Germanicus auf dem Teutoburger Schlachtfelde

5. Die römischen Rheinstädte und der römischgermanische Grenzwall

6. Die Römer als Kaufleute und Lehrmeister der Germanen

7. Die Saalburg

8. Der kimbrische Schrecken

9. Die Schlacht bei Vercellä

10. König Alarich vor Rom

11. Alarichs Ende

12. Dietrich von Bern

13. Der Ostgoten Todeskampf am Vesuv
1. Die erste Quintastunde

2. Von dem Hunde

3. Ehrfurcht vor dem Alter

4. Gerechtigkeitsliebe bei einem ganzen Volk

5. Die römischen Rheinstädte und der römischgermanische Grenzwall

6. Die Römer als Kaufleute und Lehrmeister der Germanen

7. Die Saalburg

8. Marius vernichtet die Teutonen

9. Der Untergang der Kimbern

10. Von der Gründung Roms

11. Der Raub der Sabinerinnen

12. Die letzten drei römischen Könige

13. Tib. Gracchus, der Volksfreund

The texts of chapters 2, 3 and 4 now provide exempla of particular moral qualities: fides in the case of the dog, respect for age in chapter 3 and the probitas of the Athenian citizen body in chapter 4. Chapters 10-12 include stories from early Rome, which, despite their often violent or even grisly content, seem to have been widely considered subject matter well suited for children. ${ }^{42}$ The Germanic (Gothic) invasions which toppled the Roman empire have been removed.

The passage 'Die römischen Rheinstädte und der römisch-germanische Grenzwall' ('The Roman cities on the Rhine and the Romano-Germanic border ramparts') remains almost the same. 'Die Römer als Kaufleute und Lehrmeister der Germanen' ('The Romans as merchants and teachers of the Germani') is unchanged. Passage 8 of the 1934 Ludus Latinus II reads, 'Iam secundo a. Chr. n. saeculo Germani Romanos perterruerant'. This sentence has been excised in the 1969 edition. The gleeful description of the Roman garrison's destruction at the hands of the Germani has been removed from the Saalburg passage, with its emotive reference to the success of 'maiores nostri'.

Sed iam pridem cohors illa discessit. Non iam milites Romani iis Germanis obstant, qui ad castra accedunt. Nam a maioribus nostris devicti et propulsati sunt illudque castellum, quo supra descripsimus, circumventum, expugnatum, inflammatum est ( $\left.L L A^{10} I I, 8\right)$.

Sed iam pridem illa cohors discessit. Castellum inflammatum et deletum est (LL $\left.A^{13} I I, 6\right)$.

\footnotetext{
42 Anecdotes from early Rome are staple Lehrbuch-texts. See Lat. Unt. Krüger (1967), iii (foreword of 1955 ) for the opinion that these stories are particularly suited to young beginners.
} 
The titles of passages 8 and 9 have been changed so as to shift the emphasis from the terror inflicted by the Germani on the Romans to the failure of the Cimbri and Teutones. The theme of 'furor Teutonicus', which had pervaded almost all of chapters 2 to 13 in 1934, is understated almost to the point of exclusion in the 1969 edition.

The passages that remain practically untouched, chapters 5 and 6 , give a positive interpretation of romanization that continues to fit with traditional justifications for teaching Latin as a language of culture and civilization, and a key to understanding the roots of much of European culture $\left(L L A^{10} I I, 8 ; L L A^{13} I I, 6\right)$.

From the passages of German for translation into Latin, 'Wodan', 'Siegfrieds Kampf mit Brunhild', 'Hildebrand und Hadubrand' and 'Die Raubritter' have been removed, leaving 'Der Rattenfänger von Hameln' as the only German or Germanic topic for translation. The fairy-tale of the Pied Piper is allowed to remain while the Germanic myth and history of the other passages is no longer considered suitable.

Ludus Latinus part III had, in 1932, only included one section about Germania. In the seventh edition of 1966, the passages 'Die Schlacht im Teutoburger Wald' ('The battle in the Teutoburg Forest') and 'Soldatentod' ('The death of a soldier') have been removed, along with a number of other war stories. The following table lists the changes made, illustrating the general move away from warlike subject matter. As in Ludus Latinus II discussed above, Humanist commonplaces are favoured topics of the new passages.

\begin{tabular}{ll}
\hline $\begin{array}{l}\left.\text { Passage in LL III ( }{ }^{6} 1932\right) \text { and source on which it is } \\
\text { based }\end{array}$ & Passage in LL A III $\left({ }^{7} 1966\right)$ \\
\hline $\begin{array}{l}\text { Der Opfertod des Königs Kodrus (from Val. Max. } \\
\text { 5.6.1) }\end{array}$ & Der Raub der Helena \\
Spartanische Tapferkeit (Cic. Fin. 2.97; Tusc. 1.101) & Mit wenigem zufrieden sein \\
Horatius Cocles rettet Rom (Liv. 2.10) & Flötenspieler in Rom \\
$\begin{array}{l}\text { Die Auswanderung der Plebs auf den heiligen Berg } \\
\text { (Liv. 2.32-33) }\end{array}$ & Tarquinius S. läßt das delphische Orakel befragen \\
$\begin{array}{l}\text { Die römischen Gefangenen nach der Schlacht von } \\
\text { Cannä (Cic. Off. 3.113; Gell. 6.18) }\end{array}$ & Dichter und Staatsmänner besuchen sich \\
$\begin{array}{l}\text { Die Schlacht im Teutoburger Wald (Vell. 2.117; Flo- } \\
\text { rus 2.30), Soldatentod (Inscription on gravestone of }\end{array}$ & \\
Marcus Caelius) &
\end{tabular}

Max Krüger's Lateinisches Unterrichtswerk was widely used throughout the 1950s and 1960s, especially in Berlin, where Krüger worked in the Pädagogische Hochschule of the Free University. ${ }^{43}$ It is representative of the traditional style of Übungsbuch and its subject matter involves to a great extent stories from early Roman history sourced from Livy's first decade. Anecdotes from ancient history, myth, philosophy and literature perform an exemplary function and early republican Roman values are idealized. Klaus-Dieter Thieme criticized Krüger's Unterrichtswerk for its ideology, which he saw as an outdated attempt to instil the norms

\footnotetext{
${ }^{43}$ Fritsch, 'Sprache und Inhalt' (n. 7 above), pp. 152-5. Henceforth the various versions of the textbook will be referred to as Lat. Unt. Krüger $A, B$ and $C$.
} 
of patriarchal society and 'einer frühbürgerlich-kapitalistischen Arbeits- und Leistungsgesellschaft' ('an early bourgeois-capitalist society focused on labour and productivity'). $^{44}$

Lateinisches Unterrichtswerk Krüger C I (1967) - henceforth abbreviated as Lat. Unt. - contains no passages on the Germani, though they appear in the most 'traditional' of guises in some practice sentences, for example, 'Antiquis temporibus Germani genus ferum fuerunt. Romani, cum Germanos primos vidissent, magnitudine corporum territi sunt. Eisdem hominibus opera iucunda non erant' (Lat. Unt. Krüger $\left.C^{7} \mathrm{I}, 34\right)$. In volume two there is only one text about the Germani, 'De Germanis antiquis', which is largely preoccupied with Germanic weaponry and warfare as related by Tacitus and Caesar, who are credited as the text's sources. Overall, the Germani are of little importance in Krüger's textbooks.

Latin as a third foreign language was taken only by a small number of students. Lingua Latina, a textbook for this shortened, compressed form of school Latin, beginning in year 11, takes the same approach as a number of older textbooks that had sought to compress and focus the content on the 'essentials', in that there is a heavy emphasis on Caesar. ${ }^{45}$ As a result, Roman wars with barbarians (Gauls and Germani) make up a significant proportion of the subject matter. The Romans do not, in fact, appear in any context other than their encounters with Gauls and Germani until lesson eleven of the morphology section, ${ }^{46}$ which contains 47 lessons, including 40 passages and inscriptions. Ten of these are on the subject of Germania or the Germani, mostly fairly bald adaptations of Caesar or Tacitus. After a few introductory Einzelsätze including a selection of the sort of moral commonplaces that occur throughout many textbooks of the period (' 1 . Vita vigilia est... 5. Non scholae sed vitae discimus... 8. Incolae Germaniae patriam diligunt'), our first text is 'Die alten Germanen', in which the Germani make their appearance as fearsome inhabitants of a tough country:

Incolae Asiae vel Africae vel Italiae Germaniam non petunt; metuunt enim silvas terrae et ferociam incolarum. Incolae Germaniae in pugna hastas gerunt. Galeis se non tegunt. Litteras incolae Germaniae neglegunt. Agriculturam saepe curae feminarum committunt (Lingua Latina, 11).

The passage Sueben und Ubier presents a similarly unreflective Germanenbild. In Gallic War the Suebi, and particularly their leader Ariovistus, are presented as the worst sort of barbarians: rapacious, untrustworthy and wild. The negative tone is absent from the description in Lingua Latina.

\footnotetext{
${ }^{44}$ Thieme 'Ora et labora!' (n. 12 above), p. 24. The versions which Thieme criticizes are: Meurer, H. et al. ed.; Krüger, M.; Übungsbuch A ${ }^{6}$ I (Zweite Fremdsprache) and A ${ }^{6}$ II, Frankfurt a.M./Berlin/Bonn/ Munich, 1967.

45 The edition here examined is the third (1950). Compare the comments in the introduction to the condensed, revised version of Fundamenta Linguae Latinae and the introduction to Exercitium Latinum, which was intended for schools with only one-and-a-half to two years of grammatical instruction, McNamara, 'Lehrbuchgermanen' (n. 1 above), pp. 129, 131.

${ }^{46}$ Lingua Latina is structured like many traditional Übungsbücher, with a morphology/grammar section (Formenlehre) followed by a syntax section (Satzlehre).
} 
Privatus ac separatus ager apud Suebos non est neque diu colunt agros uno in loco. Vita Sueborum libera est. A pueris sunt durati. Itaque viri excelsa statura sunt (Lingua Latina, 14).

The Germani in Lingua Latina are used as a 'familiar' point of reference for the first two lessons, after which they feature in a variety of historical situations. They are presented simply as wild but impressive. They are definitively barbarian, playing a role that fits into the focus on Caesar's Gallic war and other encounters between Romans, Gauls and Germani. Some additional Germanic subject matter includes one of the extra passages in the grammar (Formenlehre) section based on Iordanes (Getica, 29) about Alaric's burial under the river Busento. The syntax section (which follows the grammar section) has 22 lessons including further episodes from Caesar, but nothing on the Germani. ${ }^{47}$

Because Germanic antiquity, most of all Germania, became an undesirable topic in the wake of its misuse under National Socialism, schools often avoided Germania as a set text and the authors and editors of textbooks often excluded Germanic material. This should be understood as a significant change to subject matter in the context of the largely conservative textbook production of the years 1945-1970. While textbooks after 1945 were largely based on those produced under the Weimar Republic, Kulturkunde had been abandoned and large quantities of Germanic and German subject matter were no longer considered justifiable. Only in the reissued Ludus Latinus and some less commonly used texts like Lingua Latina were the Germani any longer used as a first point of identification for pupils who were being introduced to the ancient world. In Ludus Latinus there are also signs of the re-working of passages so as to avoid emotive patriotic appeals to the reader in connection with the Germani. The general lack of development in textbook methodology and the lull in academic interest in Germania precluded a fresh approach to the Germani or Germania Romana as topics of school texts. What we find, therefore, are the traditional 'Lehrbuchgermanen', now half ignored.

After 1970, new 'generations' of textbooks clearly attempt to counter the various arguments made by opponents of Latin in schools. There is an unprecedented emphasis on subject matter, both as a motivating influence for pupils and as a vital ingredient in educating children about a language and culture far removed from their own. ${ }^{48}$ An important step in justifying Latin teaching in the contemporary political and educational climate, the Lernzielmatrix produced by Klaus Westfalen and Otto Schönberger for the Deutscher Altphilologenverband in 1971 provides the framework for thematic material in the instruction of Latin, and its categories are reflected in Lehrplänen. ${ }^{49}$ The key-word Multivalenz is an important feature of this

\footnotetext{
47 There is a passage on the Nervii, who, according to Tacitus (Germ. 28.4), claim Germanic ancestry.

48 A. Fritsch, 'Sachkunde im Anfangsunterricht. Ein Überblick', Der altsprachliche Unterricht, 34.5, 1991, pp. 4-22. Kipf, Altsprachlicher Unterricht (n. 5 above), pp. 271-80.

49 Kipf, Altsprachlicher Unterricht (n. 5 above), pp. 201-14, 273; Fritsch 'Sachkunde' (n. 47 above), pp. 5-6. H.-J. Glücklich, Lateinunterricht. Didaktik und Methodik, Göttingen, 1978, pp. 197-203. The Lernzielmatrix divides subject matter into four thematic groups: 1, language; 2 , literature; 3 , society, state and history; 4, essential questions of human existence (Humanism). Each of these subject areas is to be learnt
} 
model, specifying the role of Latin as a subject that teaches more than linguistic skills. Regarding the way in which the Germani are portrayed, the rubrics 'society, state and history' and 'essential questions of human existence' provide the thematic framework, and textbooks increasingly present material and pose questions in such a way as to encourage transfer and application of concepts and knowledge to modern societal questions and problems. From the mid-1980s there was a resurgence of interest in the Germani and we see an unprecedented variety of approaches to using both Germania libera and Germania Romana as a subject for Latin passages and German informational texts. It is from the 1980s onwards that the most significant changes in the portrayal of the Germani in textbooks take place. Features of a traditional Germanenbild which remained fairly constant up to this time are in most cases drastically revised and re-interpreted, and the nature of Roman historical and ethnographic sources is called into question.

Stefan Kipf's survey of 18 Lehrpläne for the upper level (Sekundarstufe II) of secondary school Latin from across Germany between 1973 and 2003 is the most useful guide in the absence of reliable empirical analysis about the texts chosen for reading at this level. All of the Lehrpläne investigated included the traditional canonical authors Caesar, Cicero, Horace, Livy, Ovid, Sallust, Seneca, Virgil as well as Tacitus. These are amongst 163 authors who are named at least once. Lehrpläne recommend readings arranged by author, genre and theme, though thematic recommendations predominate. ${ }^{50}$ Many of the themes show an attempt to relate readings to current social questions. ${ }^{51}$

In the absence of thorough empirical evidence on the use of Germania as a school text since 1945 I shall make some anecdotal observations, the limitations of which are obvious, but which are nevertheless representative of some aspects of the text's treatment in schools. Reports on school projects in Auxilia (1989) and Der altsprachliche Unterricht (1999) show Tacitus's Germania being read in year 11 at Humanist Gymnasien. ${ }^{52}$ Eller (1987) recommends - exceptionally - Germania along with the Gallic War, the History of the Franks by Gregory of Tours, Velleius's Roman History and other texts as part of a Germani topic for year 10 students reading original Latin for the first time. ${ }^{53}$ In 1995, Schulz (1995) introduces an article on the work's interpretation as a whole with the observation that past Germanomania had rendered the work unpopular and expresses the hope that access to new research

\footnotetext{
Footnote 49 (continued)

and understood in four stages: 1, knowledge; 2, reorganization of knowledge; 3, transfer; 4, problemsolving.

50 Kipf, Altsprachlicher Unterricht (n. 5 above), pp. 384-8.

51 Kipf, Altsprachlicher Unterricht (n. 5 above), pp. 390-1.

52 F. Maier, 'Die "Germania" im Rundfunk-Studio von Schülern einer 11. Jahrgangsstufe inszeniert', in Tacitus in der Schule I, Vorschläge zur Lektüre der Germania, ed. F. Maier, Bamberg, 1989, pp. 114130. E. Rosenberger, 'Germanien in PR-Präsentationen nach Tacitus', Der altsprachliche Unterricht, 42.6, 1999, pp. 51-4.

53 G. Eller, 'Die Germanen' in Handbuch für den Lateinunterricht, Sekundarstufe I, ed. W. Höhn, N. Zink, Frankfurt a.M., 1987, pp. 310-8 (315).
} 
and new interpretative approaches will revive its popularity. ${ }^{54}$ Nevertheless, in 1995 Schulz states that it was still in schools that Germania was most often read. ${ }^{55}$

The decrease in academic attention paid to Germania after 1945 combined with the lag that usually exists between academic progress and the updating of school materials meant that it took some time for schools to have the option of using materials that were not based on work done during the 1930s. A new translation of Germania by Manfred Fuhrmann was published in 1971, offering an alternative to that of Büchner. ${ }^{56}$ Büchner's translations of the Tacitean opera minora had first appeared in 1955. A second edition was produced in 1963 and a third, with updated commentary, in 1985. Büchner's introduction, however, which was based on a 1943 lecture originally released as a military letter, presented an outdated interpretation based on the idea that, 'Jede Würdigung der Germania muß davon ausgehen, daß die Germanen in erster Linie mit Liebe und Bewunderung dargestellt werden' ('The Germania must always be appraised on the basis that the Germani are above all portrayed with love and admiration'). In this light, Büchner assesses Germania as a factual essay on the moral qualities of the Germani, of whom he claims, 'Ihr ganzes Lebensinhalt ist das Streben nach virtus' ('The whole of their life is a striving for virtus [valour/virtue]'). ${ }^{57}$

[F]rei von Wertsetzungen, die den Blick für das Echte trüben, wie Reichtum, äußerem Glanz und äußerer Schönheit, folgen sie allein dem im Göttlichen begründeten honestum als der Richtsschnur ihres Handelns, und diese Bindung ist bei äußerer Freiheit doch stärker als selbst der Tod. ${ }^{58}$

Free from an attachment to values that cloud their perception of what is authentic, such as wealth, external brilliance and external beauty, they follow only honour (honestum), which has its roots in the divine, as the thread to guide them, and with their external freedom, this commitment is stronger even than death.

The influence of this kind of interpretation is noticeable in Gerhard Eller's 1987 article in which the recommendations for teaching Germania 1-27 revolve around identifying Germanic qualities which Eller considers Tacitus to have observed 'correctly'. There is a distinct impression that some of the characteristics, such as Innerlichkeit ('inwardness') and 'innere, seelische Werte, die für den Germanen Bedeutung haben und von denen er sein ganzes Handeln... leiten läßt' ('inward, spiritual values that have value for the Germani and by which they allow their whole lives to be guided') are deutsch as much as they are germanisch, and some of the 'facts'

\footnotetext{
54 M.-W. Schulz, 'Tacitus: “Germania”, Versuch einer kurzgefaßten Gesamtinterpretation', Der altsprachliche Unterricht, 38.2, 1995, 21-39 (21).

55 Ibid. p. 21.

56 The references to Fuhrmann's translation in this essay are to a 1977 reprint.

57 A. Städele, 'Tacitus' Germania, Bericht über die Veröffentlichungen der Jahre 1976-1995 (Auswahl)', Gymnasium, 104.6, 1997, pp. 523-39 (525). K. Büchner, trans. comm. intr., R. Häussler, ed., Tacitus, Agricola, Germania, Dialogus de Oratoribus, die historischen Versuche, Stuttgart, ${ }^{3} 1985$, pp. 132, 131.

58 Büchner Tacitus (n. 56 above), 131.
} 
identified are not facts, for example, 'die Tatsache, daß Germanen... auf den Besitz von Edelmetallen keinen Wert legen' ('the fact that Germani... accord no value to the possession of precious metals'). ${ }^{59}$ The concentration on chapters 1-27 of Germania, which has traditionally been prevalent in schools, is due not only to the overwhelming number of obscure tribal names in the second half of the text, but also to the past tendency to search for facts, particularly those which could be applied to the Germani, or Germans, in general. ${ }^{60}$

Allan Lund's important Germania commentary in 1988 created a new basis for further academic work on Germania and, for researchers and schools alike, provided a thoroughgoing alternative to Rudolf Much's work. ${ }^{61}$ Lund focuses particularly on Germania as literature and presents Tacitus's ethnography in the context of the ancient ethnographic tradition, clearly identifying topoi and literary concerns behind Tacitus's text which must be considered before its value as a historical source can be assessed. Apart from Jankuhn's contributions to the third edition of Much (1967) there have been no updated commentaries in German which systematically compare Tacitus's text with the archaeological record as Rives (1999) has done in English. Archaeology is the best source of new knowledge about the Germani and Germania, and since the 1950s the dominance of Roman military archaeology has given way to an increased focus on the archaeology of non-military settlements. ${ }^{62}$ Archaeology has tended to show, and archaeologists have paid increased attention to, signs of cooperation between Germani and Romans. ${ }^{63}$ A large number of more recent exhibitions in German museums have been centred on the idea of co-operation and intercultural exchange. ${ }^{64}$ Since the 1980 s there has been renewed publication of school materials on Germania. A whole volume of the series Auxilia (volume 20, 1989) was devoted to Germania as a school text, and numerous articles have appeared in

\footnotetext{
59 Eller, 'Die Germanen' (n. 52 above), p. 313, based especially on Tac. Germ. 5. The discovery of valuable Roman metal and glass vessels in Germanic tombs indicates that possession of such items, restricted to an upper class, was a mark of status. In addition, Roman coins were widely used by the Germani, not only near the border as H. Jankuhn, 'Die Glaubwürdigkeit des Tacitus in seiner 'Germania' im Spiegel archäologischer Beobachtungen', Gymnasium Beiheft 1, 1971, pp. 142-51 (144) describes, but also amongst tribes further from the Roman empire (the 'interiores' of Tac. Germ. 5), for which see A. Lund, trans. comm. intr., Tacitus, Germania, Heidelberg, 1988, pp. 127-9. See also A. Lund, 'Versuch einer Gesamtinterpretation der 'Germania' des Tacitus, mit einem Anhang: Zu Entstehung und Geschichte des Namens und Begriffs 'Germani', Aufstieg und Niedergang der römischen Welt 33.3, 1991, pp. 18581988 (1884-8), and J. Rives, trans., comm. intr., Tacitus, Germania, Oxford, 1999, Oxford, pp. 133-5.

60 E. Rosenberger, 'Germanien' (n. 51 above), p. 51 mentions the problem of copious obscure tribal names in the introduction to his school project report.

61 Lund's work is an academic commentary.

62 T. Bechert, Römische Archäologie in Deutschland, Stuttgart, 2003, p. 76.

63 Bechert, Römische Archäologie (n. 61 above), pp. 140-2, 144-7, discusses research into the modern concepts of 'integration' and 'romanization', the concepts of natio and romanitas, and the role of the military in transmitting Roman culture and civilization.

64 The Landesmuseum Mainz presented 'Die Römer und ihr Erbe, Fortschritt durch Innovation und Integration' ('The Romans and their legacy, progress through innovation and integration') from 2 February until 25 May 2003, see Klein (2003). The Rheinisches Landesmuseum Bonn presented 'Krieg und Frieden, Kelten - Römer - Germanen' ('War and peace, Celts - Romans - Germani') from 26 July 2007 until 6 January 2008.
} 
didactic publications. ${ }^{65}$ While a number of old school editions continued to be published, new commentaries published by Städele (1983) and Haug (1988) provided new interpretative angles and greater reference to archaeological finds. ${ }^{66}$

Of the 14 new textbooks published in the years 1970-1979, only one, Roma, was conceived exclusively for use in the L1 form of school Latin. Latin taken as first, second, third or fourth foreign language, respectively, is often referred to as L1, L2, L3 or L4. Taking Latin as first foreign language had become the exception and was no longer the defining form of instruction. Latin as the second foreign language became the most widely represented course structure. ${ }^{67}$ It is worthwhile to examine the content of Roma, as it necessarily contains more material than other new textbooks and was used by pupils for whom Latin was a dominant component of their education. The introduction to Roma sets out its approach as an attempt,

den Unterricht in Latein als erster Fremdsprache zeitgemäß zu gestalten. Insbesondere sollen die zusammenhängenden Lesestücke inhaltlich ansprechen und einen systematischen Überblick über antikes Denken und Handeln aufbauen. Die mehrfarbige Bebilderung will nicht nur den Text unterstützen, sondern soll auch Freude am Umgang mit Latein vermitteln (Roma $I^{2}$ A, 3).

to give the teaching of Latin as first foreign language an appropriate contemporary form. In particular the continuous passages for reading should have engaging content and should build up a systematic overview of ancient thought and ways of life. The colourful illustrations are intended not only to support the text but also to make the encounter with Latin enjoyable.

The same intentions are behind almost all new Lateinbïcher published from this time onward. The book uses Identifikationsfiguren (central characters with whom students are supposed to identify), though in a less comprehensive fashion than many later texts, by describing the daily life of two Roman children, Marcus and Claudia, and including a Roman boy, Titus, in a number of stories.

\footnotetext{
${ }^{65}$ Eller, 'Die Germanen' (n. 52 above), p. 310-8; Maier, Tacitus in der Schule (n. 51 above); A. Städele, 'Neues von der Germania des Tacitus', Anregung 36, 1990, 156-68; A. Städele, “'Germania”-Interpretationen - gestern und heute' in Dialog Schule und Wissenschaft 17, Motiv und Motivation, ed. P. Neukam, 1993, pp. 106-24. Rosenberger, 'Germanien' (n. 51 above), pp. 51-4. The journal Der altsprachliche Unterricht has published many articles on ancient and modern ethnography which have kept the didactic literature up to date with modern research, such as C. Trzaska-Richter, 'Das römische Germanenbild und wie man es benutzte', Der altsprachliche Unterricht, 36.6, 1993, pp. 37-51; A. Lund, 'Die Erfindung der Germanen', Der altsprachliche Unterricht 38.2, 1995, pp. 4-20; A. Lund, 'Caesar als Ethnograph', Der altsprachliche Unterricht 39.2, 1996, pp. 12-23; E. Siebenborn, 'Barbaren, Naturvölker, edle Wilde', Der altsprachliche Unterricht, 41, 1998, pp. 18-31; E. Siebenborn, 'Antike ethnologische Vorstellungen in der Entdeckungsliteratur', Der altsprachliche Unterricht, 41, 1998, pp. 18-31.

${ }^{66}$ A. Städele, Cornelius Tacitus. De Origine et Situ Germanorum, Bamberg, 1983; A. Haug, Tacitus. De Origine et Situ Germanorum Liber, Frankfurt a.M., 1988.

${ }^{67}$ Kipf, Altsprachlicher Unterricht (n. 5 above), p. 281. The course Redde Rationem was produced for $\mathrm{L} 1$ and $\mathrm{L} 2 \mathrm{use}$.
} 
The Romans are often presented in a conservative fashion involving idealization of the mos maiorum and its patriarchal structure. An example is the chapter 'Die Mächtigen in Rom' ('The powerful in Rome').

Facta maiorum excitabant puerorum admirationem... Non solum pueri, sed etiam virgines facta maiorum memoria tenent (Roma $\left.I^{2} \mathrm{~A}, 90\right)$.

Saepe gravitas oris dignitatem et auctoritatem senatorum indicabat (Roma ${ }^{2}$ A, 92).

Germania and the Germani appear relatively frequently in Roma I, less frequently in volumes II and III and not at all in volume IV, which suggests that the use of Germania as a relatively familiar setting influences the construction of this course. The text 'Männer politisieren' ('Men do politics', chapter 26) is a dialogue between some Romans and a Germanus in which (by way of providing practice with possessive adjectives), each expresses his feelings about his respective homeland. Tacitus's words at Germania 2.2 have been adapted so as to shift the emphasis to patriotic sentiment.

G: Mea patria non tam pulchra est quam Italia, Romani. Caelum nostrum est asperum, crebri venti plantis nocent. Bestiae malae in nostris silvis nigris ${ }^{68} \mathrm{se}$ occultant... .

R: Natura Germanis divitias soli negat. Tamen vestram terram valde amatis.

G: Quis suam terram non amabit? - Quia patriam nostram amabamus, nostri

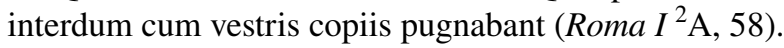

In the third volume of Roma, amongst the revision material, there is a passage based on chapters 1-2 and 5 of Germania. The sentences are all closely based on Tacitus except for one: 'Germanis autem nihil carius hac terra, quia patria est' (Roma III ${ }^{1} A$, 126). This sentiment amounts to something of a topos in traditional Latin Übungsbücher and an example of the ways in which traditional subject matter has influenced Roma. ${ }^{69}$ The word patria, which occurs only twice in Germania (at 2.2 and 31.2) and cannot be considered a major theme of the text, is a common feature of textbook passages on Germania or the Germani. When 'Germania' and 'Deutschland', 'Germani' and 'Deutsche' were used synonymously, the use of patria to refer to Germania and contemporary Germany was clear enough. The avowed patriotism of the Germani was thus intended as a model for the pupils to follow. Even in Roma, however, patria is used in a way which implies the existence of a single ancient patria

\footnotetext{
68 Neither Caesar nor Tacitus describes the forests of Germany as 'black'. The word is included here perhaps because it is idiomatic in German.

69 An early instance of this sentiment appears in 1896: 'In Germanis magnus amor patriae et libertatis erat' (Ostermann-Müller, Lateinisches Übungsbuch, 15), see McNamara (2015), pp. 96-102. An exhortation to Quinta pupils to be of service to their patria occurs at $L L^{10} I I$. 1-2. See McNamara (2015) for the pervasiveness of appeals to patriotism in textbooks from 1871 to 1945 . For a revised approach after 1945 featuring the Germani as patriotic nature-lovers, see $L L I B^{11}, 6-7$. It ought to be kept in mind that amor patriae features prominently as a defining Roman virtue in textbooks of all periods.
} 
of the Germani, a modern fantasy. Such use of patria has little to do with ancient notions of a homeland, which, for the Germanic tribes of antiquity, would have been more local than what was signified by the Roman exonym Germania. ${ }^{70}$ In Roma, as in most traditional textbooks, patria is to be understood as Germany, the pupils' fatherland - an echo of the old conflation of Germania and Deutschland.

Chapters 26 and 27 of volume I deal with the ancient theme of discordia as the bane of the Germani. ${ }^{71}$ 'Germanische Zwietracht' ('Division among the Germani', chapter 27) uses the encounter of Flavus and Arminius across the river Weser (Tac. Ann. 2.9-10) as its basis and presents a simple version of the brothers' arguments in dialogue form. It is summed up by the Roman from the previous chapter: 'Clarum exemplum discordiae narras. Quis vitia vestra sanabit?' (Roma $\left.I^{2} A, 60\right)$.

The Germani next feature in chapter 32, where the boy Titus marvels at the view of Rome from the Capitol. Suddenly he is struck with concern that Rome's greatness could be transient: 'Ego interdum in metu sum propter Germanos. Nam pater de tumultu Germanorum narrabat. Instatne nos periculum?' (Roma $\left.I^{2} A, 70\right)$ Uncle Publius assures the young Titus that discordia amongst the barbarians will be to the Romans' advantage and that Roman armies will always be strong enough to ward off their enemies. The fall of Rome is a relatively uncommon topic for textbook passages and although there are hints at the catastrophic Gothic invasions of the fourth and fifth centuries, the passage is still set during the early empire. Although Roma represents a new generation of textbooks in terms of its methodology, much of the subject matter remains rooted in the traditions of Latin textbooks, which can fairly be described in some instances as topoi.

During the 1980s there were only 5 new school Latin courses published in Germany alongside numerous new editions of older post-war publications. ${ }^{72}$ Ostia was first published in 1985 and offers a new degree of lavish illustration and colourful presentation. Its chapters cover a very broad range of topics about the ancient world. Only one, however, includes material on the Germani. A lengthy text in German describes Romano-Germanic encounters and comments on the biases inherent in the Gallic War and Germania. This is important for putting into perspective the humorous passage 'Die Germanen: kräftige Sklaven, Bernstein, rauhe Sitten' ('The Germani: powerful slaves, amber, rough customs'), in which Roman parents tell

\footnotetext{
70 A relevant passage of Germania is at 10.6, where the adjective patrius refers to weapons from the respective patriae of two champions whose combat is intended to predict the outcome of an impending war between their tribes. The meaning of patrius is specific to each tribe rather than being "panGermanic'.

71 The classic reference to Germanic discord is Tacitus's gleeful description of the massacre of 60,000 Bructeri by their Germanic neighbours (Ger. 33). Tiberius's policy of allowing Germanic disunity, rather than Roman offensives, to weaken Rome's enemies east of the Rhine was successful (Tac. Ann. 2.26).

72 Kipf, Altsprachlicher Unterricht (n. 5 above), pp. 281-2. One of the re-issued textbooks was Ars Latina. The 1983 version is based on an edition of 1965. Its two passages on the Germani are 'De Romanis, Germanorum praeceptoribus' and 'Arminii et Flavi fratrum colloquium' (Ars Latina [neubearbeitet] I, 57-9). The former passage describes the admiratio of the Germani for Roman civilization (notably towns and comfortable villas) and their debt to Roman 'scientia agriculturae'. The dispute between Arminius and Flavus is a straightforward dialogue based on Tacitus's Annals 2.9-10, presenting Arminius's arguments in favour of loyalty to his patria and Flavus's advocacy of accepting Roman superiority.
} 
their children stories about wild Germanic customs that are at first attractive (when the children hear that the Germani have no school) and then repellent - when they hear that Germanic fathers may gamble away their children's freedom, or that the Germani bathe in frigid water (Ostia $\left.{ }^{l} I, 100-103\right)$. The teachers' handbook compares the 'Klischeevorstellungen' ('stereotypical ideas') and occasional 'naiv[e] Bewunderung' ('naïve admiration') behind Tacitus's ethnography with the lack of understanding shown by Europeans in early encounters with indigenous peoples of Africa, America and Australia (Ostia, Lehrerkommentar, 81). The brief inclusion of the Germani in Ostia therefore takes an approach based on productive scepticism towards ancient source material and its prejudices, which leads to the application of critical thinking to other instances of intercultural misunderstanding. Such themes are to become common in later textbooks which pay more attention to the Germani and Germania Romana.

\section{Conclusions}

During the period in focus here, the aversion to material tainted by its ideological appropriation by National Socialism is perceptible through the paucity of academic publications on Germania. New editions of school textbooks issued after 1945 show that Germanic material appears less frequently, and the use of headings to direct reader responses shows changes in emphasis, away from some of the more emotive attitudes and direct calls to identify with the Germani as Deutsche. Nevertheless, aversion to the material also allowed many long-lived clichés to persist unchallenged. Contemporary politics appear to have continued to serve as a reference point in portrayals of ancient Germany, and references to the divisions amongst the ancient Germani may have resonated with the contemporary division between East and West Germany. It is not until the 1980s that a more critical attitude to Roman portrayals of the Germani is perceptibly encouraged in textbooks, around the time when broader public interest in ancient Germania started to rise again. The period of more intensive reception of ancient texts about the Germani, and their adaptation in art and education after the unification of the Federal Republic and the German Democratic Republic constitutes the object of further research.

Funding Open Access funding enabled and organized by Projekt DEAL. The research was funded by a Victoria University of Wellington Masters by Thesis scholarship and a New Zealand Postgraduate Study Abroad Award.

\section{Compliance with Ethical Standards}

Ethical Approval The research was granted ethical approval by Victoria University of Wellington.

Open Access This article is licensed under a Creative Commons Attribution 4.0 International License, which permits use, sharing, adaptation, distribution and reproduction in any medium or format, as long as you give appropriate credit to the original author(s) and the source, provide a link to the Creative Commons licence, and indicate if changes were made. The images or other third party material in this article 
are included in the article's Creative Commons licence, unless indicated otherwise in a credit line to the material. If material is not included in the article's Creative Commons licence and your intended use is not permitted by statutory regulation or exceeds the permitted use, you will need to obtain permission directly from the copyright holder. To view a copy of this licence, visit http://creativecommons.org/licen ses/by/4.0/.

\section{Appendix: List of School Textbooks and Teachers' Resources Consulted:}

The format is based on that used by Kipf, Altsprachlicher Unterricht (n. 5 above): texts are ordered alphabetically by title. Editions of Ludus Latinus are listed chronologically.

Ars Latina, Lateinisches Unterrichtswerk für grundständiges Latein(I), auf der Grundlage der Ausgabe von 1965, G. Boekhorst, A. Reiff, Paderborn, ${ }^{1} 1983$.

Exercitia Latina für Latein als 2. Fremdsprache (IV: Übungs- und Lesebuch),

R. Hornung, Bamberg/Munich, ${ }^{5} 1974$.

Exercitium Latinum, Lese- und Übungsbuch, G. Röttger, Leipzig/Berlin, 1941.

Experientia. A Modern Practice Book for 'O' Level Latin, S. Morris, London/ Toronto/Wellington/Sydney, 1957.

Fundamenta Linguae Latinae, Lateinisches Lehr- und Lesebuch (I A für die dritte Klasse der Oberschule), L. Voit, H. Zinsmeister, Bamberg/Munich/Berlin/ Reichenberg, ${ }^{5} 1942$.

Lateinisches Übungsbuch im Anschlu $\beta$ an ein grammatisch geordnetes Vocabularium, (I: Sexta), C. Ostermann, Leipzig, ${ }^{8} 1872$.

Lateinisches Übungsbuch (I: Sexta), C. Ostermann, H. Müller, Leipzig, ${ }^{5} 1896$.

Lateinisches Unterrichtswerk I, E. Bornemann, Frankfurt a.M., ${ }^{3} 1949$.

Lateinisches Unterrichtswerk II, Erklärungen und Anregungen für den Lehrer,

E. Bornemann, Frankfurt a.M. [year unstated].

Lateinisches Unterrichtswerk (I C) [neu bearbeitet], E. Bornemann, E. Gebhardt, et al. Frankfurt a.M., 1981.

Lateinisches Unterrichtswerk (I C), M. Krüger, Frankfurt a.M., ${ }^{7} 1967$.

Lateinisches Unterrichtswerk (II C), M. Krüger, Frankfurt a.M., ${ }^{4} 1964$.

Lateinisches Unterrichtswerk, Lese- und Übungsbuch (I), L. Mader, O. Wecker, Frankfurt a.M./Berlin, ${ }^{1} 1938$.

Lateinisches Unterrichtswerk, Lese- und Übungsbuch (II), L. Mader, O. Wecker, Frankfurt a.M./Berlin, ${ }^{3} 1940$.

Lingua Latina, Lateinisches Lehr- und Übungsbuch für Anstalten mit Lateinbeginn im 9.Schuljahr, Berlin/Leipzig, ${ }^{3} 1950$.

Ludus Latinus, Lateinisches Lese- und Übungsbuch für Sexta, G. Boesch, G. Michaelis, Leipzig/Berlin, ${ }^{1} 1926$.

Ludus Latinus, Lateinisches Unterrichtswerk für Schulen mit grundständigem Unterricht (III:Quarta), G. Salomon, Leipzig/Berlin, ${ }^{6} 1932$.

Ludus Latinus, Lateinisches Unterrichtswerk für Schulen mit grundständigem Unterricht (II für Quinta), F. Wolff, Leipzig/Berlin, ${ }^{10} 1934$.

Ludus Latinus, Übungsbuch (IV A), G. Röttger, Leipzig/Berlin, ${ }^{8} 1936$.

Ludus Latinus (III / IV B), G. Röttger, Leipzig/Berlin, ${ }^{12 / 9} 1938$. 
Ludus Latinus (I B), Stuttgart, ${ }^{11} 1963$.

Ludus Latinus, Lateinisches Lese- und Übungsbuch (III), W. Hartke, G. Michaelis, Stuttgart, ${ }^{7} 1966$.

Ludus Latinus. Lese- und Übungsbuch (II A), ${ }^{13} 1969$.

Ostia, Lateinisches Unterrichtswerk. Band 1, W. Siewert et al., Stuttgart, ${ }^{1} 1985$.

Ostia, Lehrerkommentar, K. Weddigen et al., Stuttgart, 1988.

Roma, Unterrichtswerk für Latein als 1. Fremdsprache (I: Römisches Leben), R. Ernstberger, H. Ramersdorfer, Bamberg/Munich, ${ }^{2} 1984$.

Roma, Unterrichtswerk für Latein als 1. Fremdsprache (II: Sagen, Fabeln und Legenden), W. Bosch, L. Häring, Bamberg/Munich, ${ }^{2} 1985$.

Roma, Unterrichtswerk für Latein als 1. Fremdsprache(III: Geschichten aus der alten Welt), G. Hertel, G. Wojaczek, Bamberg/Munich, ${ }^{1} 1985$.

Roma, Unterrichtswerk für Latein als 1. Fremdsprache (IV: Römisches Denken, Reden und Handeln), H. Brumberger, et al., Bamberg/Munich, ${ }^{1} 1986$.

Publisher's Note Springer Nature remains neutral with regard to jurisdictional claims in published maps and institutional affiliations. 